\title{
Legal Regulations and Branding Higher Education Institutions
}

\author{
Syed Ali Abbas ${ }^{1}$ \\ ${ }^{1}$ Turiba University, Riga, Latvia \\ Correspondence: Syed Ali Abbas, Turiba University, Riga, Latvia. Email: aabbas724@gmail.com
}

Received: September 27, 2017

Accepted: October 11, 2017 Online Published: October 11, 2017

doi:10.20849/ajsss.v2i3.195

URL: https://doi.org/10.20849/ajsss.v2i3.195

\begin{abstract}
With the advancement in technology the demands for businesses are increasing, exactly the way compliance with legalities and rules and regulations have become a must for businesses to reach their peak. Considering the very scenario, this review paper aims to recon the importance and linkage of branding with laws and legislation required to brand a specific product/ service. Most importantly the current trend in higher education branding entails ways for rigorous marketing which universities and HEIs (Higher Education Institutions) are doing to promote themselves. From TV ad to Social media and from promotional flexes to gorilla marketing, universities are leaving no stone unturned to band themselves. However, their branding approach and campaigns are bound to comply with local laws of their respective countries which are governed by cultural and geographical constraints as well. Therefore this analysis based commentary forms bases for future research comprising of branding and legislation as a determinant of the intensity and limit for branding, thus focusing the importance of mercantile law with business world.
\end{abstract}

Keywords: laws, higher education laws, branding laws, marketing regulations, cultural legalities

\section{Introduction}

Considering the modern methodologies and increasing trends in promotional activities worldwide, a marketer ought to be abide by the rules and regulations set by Government and regulatory authorities in the demographics he/ she is operating. These legal constraints do affect and guide a marketer/ advertiser that what and how marketing strategies should be made and executed which must be aligned with the country's law and legislature. As Shleifer et al (1997) states that common law countries provide the strongest whereas countries following French Civil law offer the weakest protection to shareholder's interest, these legal barriers allow marketers to better analyze and craft promotional activities in accordance with the prerequisites of Laws and legislature. As for the fact, research work needs to be carried out in the domain of Branding of Higher education institutions in which various promotional and advertising campaigns are formulated along with cross comparison of countries, it is extremely important to understand the legal aspects of higher education and branding so as to counter prospect legal issues, if any.

\subsection{Legal Regulations and Businesses}

No business can get the desired level of success and profitability if not accompanied by law. From accreditation to firm registration, owning stocks to audit reports and from measuring brand equity to offshoring companies; abiding by the law is must for a business to operate. The research concerning Higher Education branding across various countries" makes Law as core basis for the study. It will be interesting to know the role of various legal families affecting the terms of promotion in different countries. The legal questions that are linked to administrative law and commercial law require immense reasoning and logic as far as branding and promotion is concerned. Few of them could be the nature of branding activities and its permission in administrative or commercial law, the disclosure of specific information about institution as per law and the administrative law concerning the level of state involvement in institution's own policy making are few of the things that needs to be looked upon. However at this point it is important to understand the difference between Administration and Management in legal perspective.

Administration is top level work whereas management account for middle management. Administration is determinative function and found mostly in military, religious and educational institutions. Keeping this point in view, it will be essential to not to mix administrative tasks with management orientation as the former quantifies planning and organizing of functions and resources whereas management involves regulating and managing the 
staff and motivating employees. It won't be wrong to comment that law defines a fine line between administration and management and that management acts on lines guided by the administration.

\section{Objectives of the Study}

As discussed above, the intended review is being carried out to know the importance of law and legislation for branding of higher education institutions (HEIs) and to design/ develop/ implement new laws for brand management, if required.

\subsection{Legal Terms in Business}

Brand Equity: The total financial and monetary worth of a brand over a period of time.

Acceptance: The unconditional acceptance to an offer.

Agent: Someone who is appointed on behalf of some other person to carry on proceedings. To what level the agent may carry is written in the contract.

Conditions: Accounts for terms of the contract.

Consumer: A person who is entitled to buy goods and services from the business but not a part of business.

Share Holder: The one who has shares in the company. He/ she is a stake holder also.

Stake Holder: The one who may have stake in the company because of its operations and procedures. $\mathrm{He} / \mathrm{She}$ may not be a shareholder.

Franchising: Commercial agreements allowing a business to sell or control other's business on specified terms.

Joint Venture: An agreement between two different businesses to bring about new business.

Mergers: Two businesses sharing part of their resources in existing business.

Acquisition: Business acquiring another business in total.

Liquidation: The insolvency of a business may be because of lack of paying dividends or in ability to pay bank's liability.

Void: A contract that can't be completed at all.

Legal duty: The responsibility to other to act according to law.

Bona fide: Implies parties are acting in good faith.

Mala fide: in bad faith. Opposite to bonafide.

Cavet Emptor: Awareness of consumer. That's it's up to the consumer to know he/ she is buying what he/ she wants.

De novo: starting afresh. A new contract

Quid pro quo: something for other. That each party must offer something to other.

\subsection{Legal Constraints in Branding}

The legal constraints in branding of any organization specifically any institution/ university can have few constraints to work on. These could be in the initial as well as in later stages. Talking precisely on branding the first thing comes is the name of institute/ university which in general may have clear meanings, not dubious or in some countries must not be an already opted name by Government. So before naming an institution, one would have to affirm if a private institute may opt a name resembling legal or Government office, e.g. Parliament is an official place of sitting for ministers dealing with parliamentary affairs, therefore can a university have a name like "University of Parliament" unless Government opts to open one. Similarly other integral aspects of branding include the logos, trademarks, slogans or the tag lines. It is important for educational institute to not to use culture sensitive logo, religiously insane slogans and unethical tag lines in accordance with the laws and legislature of a state. As in Muslim \& Hindu Law, claiming and granting ancestor's property and routine affairs is practiced by their respective laws, yet for business and commercial issues Hindu law is seen impressed by Common Law (Zweigert, 1987). So no wonder if an institute may initially operate with these sensitive trademarks and advertisement campaigns, however at later stages the overall branding gets affected in the long run where the state's own law is also in operation along with common law. Therefore, considering the research work focusing on brand management it is important for higher education institutions to look over legal barriers for a successful and trusted branding. Other things to look upon legally in education branding include:

Advertisement and promotional campaigns 


\section{$>$ Course curriculum}

$>$ Events and celebrations organized by Universities

$>$ Political/ religious activities/ associations in institutes

\subsection{Country Specific Laws in Data Collection for Branding}

Since research focusing on comparative analysis among various countries requires data collection from various sources and may be different geographical regions, it may be a hard task to collect data and to actually identify the limit which the law allows to collect and publish the very data. In simple words collecting a data from German university regarding its marketing and in depth strategies may have different repercussions if a data with same attributes is collected from an Asian university. Not only the procedures and the length of data be varied but it will be the publication rights which may differ. For instance as per (BDSG) German Federal Data Protection Act, a justification can be required if data processor is located outside Germany, whereas no justification will be required if both the data controller and data processor reside in Europe. Therefore having awareness with the law/ regulations before starting data collection would be extremely essential.

\subsection{Disclosure of Important Info}

Again the law in different countries is different for disclosure of necessary info. The information which may include the number of students, number of courses, funding by the financial institutes etc. may not be easily allowed to publish. Most importantly, countries with high corruption index are seen to be sheltered by laws and regulations advocating the bureaucratic corruption or the amendments are made with addition or subtraction of clauses. Hence, these laws/ ordinances don't permit open dissemination of information with the real purpose of hiding corruption or income generated by unfair means.

\section{Conclusion}

Understanding the law and implementing the law are two different things which can prove out to be decisive for any business firm. As this commentary focuses on the prospect research on higher education branding, it is concluded without any doubts that the implementation of laws and its execution are evenly important in universities as well and conducting a marketing research on the methods of branding being carried out by these universities require a lot to do with the law. Be it data collection or reviewing an advertising strategy, it will be important for researcher to not to overlook the legal aspects behind these. Also, as education sector entails to be the epitome of novelty, the responsibility to brand an institution should not collide with ethics and morality of social setup in which it is being operated. Therefore, sector specific laws need to be incorporated more in this diverse field of education so that higher education branding turns out be value driven both in terms of quality and quantity of customers (students). As discussed above that from brand name to brand strategy it's the legal aspects which somehow govern this whole marketing effort that's why imparting more and more laws and abiding by legalities in brand communication should act as basis for conducting an effective research on branding.

\section{Implications for Future Research}

The following study my initiate further research by

- Focusing on joint research comprising on law and marketing, which has unfortunately been very scarce.

- Initiating research on branding of higher education institutions and application of laws and regulations required to brand HEIs.

- Making universities to design and incorporate law related courses in basic business studies.

- Allowing researchers to highlight the importance of law and ethics in business among common public.

- Emphasizing on developing new laws required to brand specific educational band.

\section{References}

business contracts legal terms and definitions glossary. (n.d.). businessballs.com. Retrieved from http://www.businessballs.com/businesscontractstermsdefinitionsglossary.htm

CORRUPTION PERCEPTIONS INDEX 2015. (n.d.). Transperency International. Retrieved from http://www.transparency.org/cpi2015

Practical Law - A Thomas Reuters Legal Solution. (2015). Data protection in Germany. Retrieved from http://uk.practicallaw.com/3-502-4080\#

Shleifer, Andrei, \& Vishny, Robert W. (1986, June). Large Shareholders and Corporate Control. J.P.E. 94(3), pt. $1,461-88$. 
Thorsten Beck, \& A. D.-K. (2002). FINANCIAL AND LEGAL CONSTRAINTS TO FIRM GROWTH: DOES SIZE $M A T T E R ?$ Retrieved from http://siteresources.worldbank.org/INTFR/Resources/FinancialAndLegalConstraintsToFirmGrowth.pdf Zweigert, Konrad, \& Kotz, Hein. (1987). An Introduction to Comparative Law (2d rev. ed.). Oxford: Clarendon.

\section{Copyrights}

Copyright for this article is retained by the author(s), with first publication rights granted to the journal.

This is an open-access article distributed under the terms and conditions of the Creative Commons Attribution license (http://creativecommons.org/licenses/by/4.0/). 